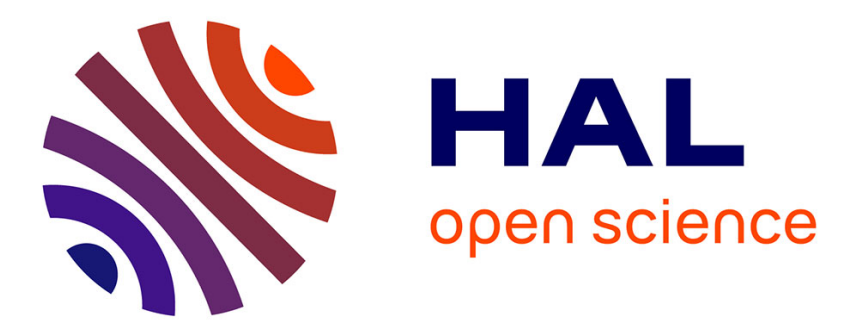

\title{
Involvement of drug transporters in the synergistic action of FOLFOX combination chemotherapy
}

\author{
Dirk Theile, Sina Grebhardt, Walter Emil Haefeli, Johanna Weiss
}

\section{To cite this version:}

Dirk Theile, Sina Grebhardt, Walter Emil Haefeli, Johanna Weiss. Involvement of drug transporters in the synergistic action of FOLFOX combination chemotherapy. Biochemical Pharmacology, 2009, 78 (11), pp.1366. 10.1016/j.bcp.2009.07.006 . hal-00524464

\section{HAL Id: hal-00524464 \\ https://hal.science/hal-00524464}

Submitted on 8 Oct 2010

HAL is a multi-disciplinary open access archive for the deposit and dissemination of scientific research documents, whether they are published or not. The documents may come from teaching and research institutions in France or abroad, or from public or private research centers.
L'archive ouverte pluridisciplinaire HAL, est destinée au dépôt et à la diffusion de documents scientifiques de niveau recherche, publiés ou non, émanant des établissements d'enseignement et de recherche français ou étrangers, des laboratoires publics ou privés. 


\section{Accepted Manuscript}

Title: Involvement of drug transporters in the synergistic action of FOLFOX combination chemotherapy

Authors: Dirk Theile, Sina Grebhardt, Walter Emil Haefeli, Johanna Weiss

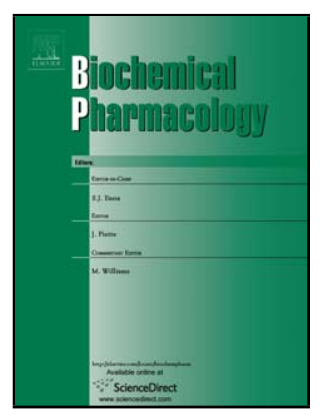

PII:

S0006-2952(09)00635-2

DOI: doi:10.1016/j.bcp.2009.07.006

Reference: BCP 10261

To appear in: $B C P$

Received date: 11-5-2009

Revised date: 9-7-2009

Accepted date: 10-7-2009

Please cite this article as: Theile D, Grebhardt S, Haefeli WE, Weiss J, Involvement of drug transporters in the synergistic action of FOLFOX combination chemotherapy, Biochemical Pharmacology (2008), doi:10.1016/j.bcp.2009.07.006

This is a PDF file of an unedited manuscript that has been accepted for publication. As a service to our customers we are providing this early version of the manuscript. The manuscript will undergo copyediting, typesetting, and review of the resulting proof before it is published in its final form. Please note that during the production process errors may be discovered which could affect the content, and all legal disclaimers that apply to the journal pertain. 
Involvement of drug transporters in the synergistic action of FOLFOX combination chemotherapy

Dirk Theile ${ }^{1}$, Sina Grebhardt ${ }^{1}$, Walter Emil Haefeli, Johanna Weiss

Department of Internal Medicine VI, Clinical Pharmacology and Pharmacoepidemiology University of Heidelberg

Im Neuenheimer Feld 410, D-69120 Heidelberg, Germany

\section{Corresponding author:}

PD Dr. Johanna Weiss

Department of Internal Medicine VI, Clinical Pharmacology and Pharmacoepidemiology University of Heidelberg

Im Neuenheimer Feld 410, 69120 Heidelberg, Germany

Phone: $+49622156-39402$

Fax: +49 6221 56-4642

E-mail: johanna.weiss@med.uni-heidelberg.de

${ }^{1}$ Dirk Theile and Sina Grebhardt contributed equally to this manuscript 


\section{Abstract}

FOLFOX is a cytostatic drug combination for adjuvant treatment of colorectal cancer (CRC) consisting of 5-fluorouracil (5-FU), leucovorin, and oxaliplatin. The mechanism of synergistic interaction of these drugs is poorly understood and little is known concerning the role of drug transporters and the impact of oxaliplatin metabolites oxalate and dichloro-diaminocyclohexane platinum. We therefore investigated the influence of FOLFOX-components on drug transporter expression by quantitative real-time polymerase chain reaction and on the efficacy of each FOLFOX component by proliferation assay in the CRC model cell line LS180. Control experiments with transporter over-expressing cell lines were used to assess the significance of important transporters for the cytostatic activity of FOLFOX components. Moreover, we assessed the pharmacological contribution of the oxalato-ligand to the effect of oxaliplatin. FOLFOXcomponents led to several alterations in expression of drug transporters. For instance, 5-FU significantly suppressed ATP7B and human organic cation transporter 2 and increased multidrug resistance associated protein (MRP) 2 mRNA expression (5.8-fold). This was accompanied by a significant sensitisation to oxaliplatin. Over-expression of certain ABC-transporters (BCRP/ABCG2, MRP2/ABCC2 or MRP3/ABCC3) was demonstrated to be beneficial for the efficacy of oxaliplatin. The results obtained indicate that both down- and up-regulations of drug transporters could favour synergistic action of this drug combination. Moreover, oxaliplatin metabolite oxalate seems to positively modulate oxaliplatin's action as elucidated by median effect analysis. In conclusion, we propose as one mechanism for FOLFOX synergism the 5-FU mediated suppression of ATP7B, the over-expression of glutathione exporters such as MRP2/ABCC2 and the decrease of glutathione levels by oxalate.

Key words: Colorectal cancer, FOLFOX, synergism, drug transporters, glutathione, oxalate. 


\section{Introduction}

The addition of oxaliplatin to standard chemotherapy with 5-fluorouracil (5-FU) and folinic acid (leucovorin) (FOLFOX regimen) has substantially improved the outcome of patients with colorectal cancer (CRC) [1]. The mode of synergistic interaction between these compounds, however, is not well investigated. Moreover, also the potential role of drug transporters limiting access of chemotherapeutic agents and co-factors to CRC cells has been addressed [2,3], but their role in the FOLFOX regimen has not been thoroughly investigated.

The ATP-binding cassette (ABC-) transporter superfamily contains several family members that may confer intrinsic or acquired multidrug resistance (MDR) by extruding anticancer agents or their metabolites from cells [4] and suppression of such transporters may lead to sensitisation to cytostatic agents [5]. Indeed, BCRP/ABCG2 and several members of the multidrug resistanceassociated protein (MRP/ABCC) family have been identified as folate export transporters [6] and the activity of both, MRP5/ABCC5 and MRP8/ABCC11 have been linked to MDR to 5-FU [7,8]. In contrast, transport processes may also promote antineoplastic action. The distribution of Pt containing antineoplastic agents is regulated by copper homeostasis components. As an example, human copper transporter 1 (hCTR1/SLC31A1) mediates the cellular uptake of copper, cisplatin, and oxaliplatin [9]. In addition, the two P-type ATPases ATP7A and ATP7B are also associated with transport and resistance to oxaliplatin, either by promoting efflux out of the cell or by sequestration into subcellular compartments [10]. Human organic cation transporter 2 (hOCT2/SLC22A2) was also shown to mediate oxaliplatin uptake [11]. Moreover, glutathione, which inactivates cisplatin and oxaliplatin by conjugation $[12,13]$, is exported by several MRPs/ABCCs, either alone, as co-substrate, or in its conjugated form. Thus, enhanced MRP/ABCC expression can lead to decreased cellular glutathione content [14]. 
The aim of this in vitro study was to scrutinise the mode of synergistic action of FOLFOX components by evaluation of their effects on both expression of drug transporters and cytostatic properties and to assess the pharmacological contribution of the oxalato ligand to oxaliplatin's effect, because it is well known that oxalate has profound effects on redox status [15], production of radical oxygen species [16], and cytotoxic properties of Pt drugs [17]. 


\section{Materials and Methods:}

\subsection{Materials}

Culture media, foetal calf serum (FCS), medium supplements, antibiotics, glutamine, phosphate buffered saline (PBS), and 5-chloromethylfluorescein diacetate (CMFDA) were purchased from Invitrogen (Karlsruhe, Germany). Acetylcystein, dimethyl sulfoxide (DMSO), 2-(Nmorpholino)ethanesulfonic acid (MES), aprotinin, dichloro-diaminocyclohexane (DACH)platinum $\left(\mathrm{Cl}_{2}\right.$-DACH-Pt), DACH, leucovorin, 5-FU, and verapamil hydrochloride were purchased from Sigma-Aldrich (Taufkirchen, Germany) and bromphenol blue from Biomol (Hamburg, Germany). Crystal violet, Triton $^{\circledR}$ X-100, NaCl, TRIS, dithiothreitol (DTT), glycerol, sodium dodecylsulfate (SDS), $\mathrm{H}_{2} \mathrm{O}_{2}$, and oxalic acid were from AppliChem (Darmstadt, Germany). Methanol was from Roth (Karlsruhe, Germany), p-coumaric acid and luminol from Fluka (Basle, Switzerland). MK571 was from BIOMOL Research Laboratories (Plymouth Meeting, USA). 96-well microtiter plates were from Nunc (Wiesbaden, Germany) and cell culturing bottles were from Greiner (Frickenhausen, Germany). Pheophorbide A (PhA) was from Frontier Scientific Europe (Carnforth, Lancashire, UK) and collagen R and pefabloc were from Serva (Heidelberg, Germany). Calcein acetoxymethyl ester was purchased from MobiTec (Göttingen, Germany), leupeptin and pepstatin from Biomol (Hamburg, Germany), and rhodamine-123 and Tween-20 from Calbiochem (Darmstadt, Germany). Fumitremorgin C was kindly provided by the National Cancer Institute (Rockville, MD, USA). RNA isolation kit RNeasy Midi-Kit was from Qiagen (Hilden, Germany). Cytotoxicity Detection Kit and materials for real time PCR were from Roche Applied Science (Mannheim, Germany). RevertAid ${ }^{\mathrm{TM}} \mathrm{H}$ Minus First Strand cDNA Synthesis Kit was from Fermentas (St. Leon-Rot, Germany). Absolute QPCR SYBR Green Mix was from Abgene (Hamburg, Germany). QuantiChrom Glutathione 
Assay Kit was obtained from BioAssay Systems (Hayward, CA, USA). Oxaliplatin and cisplatin were obtained from the University Hospital's pharmacy.

\subsection{Cell lines}

The cell line LS180 (available at ATCC, Manassas, VA, USA), a cell line derived from human colon adenocarcinoma, was used to investigate changes of drug transporter mRNA expression by induction [18] and to estimate the reciprocal effects on cytostatic properties of the drugs used. Cells were cultured under standard cell-culture conditions as described previously [18] and were seeded 3 days before the assay.

As an in vitro model for human Pgp, BCRP, MRP1, MRP2, and MRP3, we used Madin-Darby canine kidney II cells (MDCKII) over-expressing the corresponding transporter. All cell lines were generated by stable cDNA transfection into MDCKII cells and were provided by Dr. Piet Borst and Dr. Alfred H. Schinkel (The Netherlands Cancer Institute, Amsterdam, The Netherlands). Parental MDCKII/Par cells served as a control. Cells were cultured in Dulbecco's modified Eagle's medium supplemented with $10 \%$ heat inactivated foetal calf serum, $2 \mathrm{mM}$ glutamine, $100 \mathrm{U} / \mathrm{ml}$ penicillin, and $100 \mu \mathrm{g} / \mathrm{ml}$ streptomycin sulphate.

The murine monocytic leukaemia cell line P388 and the corresponding doxorubicin-resistant cell line P388/dx over-expressing mdr1a/1b were used to estimate the Pgp inhibiting properties of DACH and oxalate as described before. This cell system has proved to be the most suitable for evaluation of Pgp inhibition [19].

\subsection{Proliferation assay}

Cell proliferation was quantified by crystal violet staining [20]. Cells were seeded onto collagencoated 96-well microtiter plates and preincubated for $24 \mathrm{~h}$. After addition of test compounds, cells were incubated for another $48 \mathrm{~h}$. Cells were then washed with PBS and stained with crystal violet $0.5 \%$ as described previously [20]. Absorption was measured using a Multiskan RC 
photometer with $555 \mathrm{~nm}$ excitation. Proliferation was expressed as proliferation index by calculating crystal violet absorption intensity as percentage relative to baseline (absorption intensity of medium-only wells (set to $0 \%$ )) and native proliferation (absorption intensity of untreated cells (set to 100\%)). Each concentration was tested in octuplets and each assay was performed thrice.

\subsection{Pretreatment of cells with FOLFOX components}

LS180 cells were cultured in culture flasks for 24 h to $70 \%$ confluence. Subsequently, cells were incubated for another $72 \mathrm{~h}$ with the $\mathrm{IC}_{20}$ of the particular drug (leucovorin $1.52 \mathrm{mM}, 5-\mathrm{FU} 7.14$ $\mu \mathrm{M}$, or oxaliplatin $0.20 \mu \mathrm{M}$ ). After incubation, cells were washed, trypsinised, and seeded onto collagen-coated 96-well microtiter plates. The subsequent proliferation assays were conducted as described above.

\subsection{Quantification of transporters' $m R N A$ expression}

RNA was isolated using the RNeasy Mini-Kit. Quality and concentration was measured spectrophotometrically and isolated RNA was stored at $-80^{\circ} \mathrm{C}$ until analysis. cDNA was synthesised with the RevertAid ${ }^{\mathrm{TM}}$ H Minus First Strand cDNA Synthesis Kit according to the manufacturer's instructions. mRNA expression of the respective genes was quantified by realtime reverse transcriptase polymerase chain reaction (RT-PCR) with a LightCycler ${ }^{\mathrm{TM}}$ (Roche Applied Science, Mannheim, Germany). PCR amplification was carried out in $20 \mu 1$ reaction volume with the LightCycler-FastStart DNA Master SYBR Green I or with the Absolute QPCR SYBR Green Mix. Primers used are summarised in Table 1. The most suitable housekeeping gene for the cytostatic treatment of LS180 cells was identified using geNorm (version 3.4, Center for Medical Genetics, Ghent, Belgium). Among the housekeeping genes tested ( $\beta 2$-microglobulin ( $\beta 2 m g)$, glucose-6-phosphate dehydrogenase (G6PDH), glucuronidase $\beta(G U)$, hypoxanthinephosphoribosyltransferase 1 (HPRT), ribosomal protein L13 (RPL13), and 60S (human) acidic 
ribosomal protein P1 (HUPO) GU proved to be the most stable in LS180 cells under the assay conditions. Data were evaluated by calibrator-normalised relative quantification with efficiency correction using the RelQuant software version 1.01 (Roche Applied Science, Mannheim, Germany) as published previously [21]. All samples were amplified in duplicate or triplicate.

\subsection{Western blot analysis}

To confirm induction of MRP2/ABCC2 after 5-FU treatment and reduction of Pgp/ABCB1 after oxaliplatin treatment at protein level, we analysed whole cell lysates of the corresponding cells by western blot analysis. Trypsinised cells were washed once with PBS. The pellet was homogenised on ice in $500 \mu$ lysis buffer (pH 6.5) containing $25 \mathrm{mM}$ MES, $150 \mathrm{mM} \mathrm{NaCl}$ and a combination of protease inhibitors $(1 \mathrm{mg} / \mathrm{mL}$ pefabloc, $5 \mu \mathrm{g} / \mathrm{mL}$ leupeptin, $1 \mu \mathrm{g} / \mathrm{mL}$ pepstatin, and $1 \mu \mathrm{g} / \mathrm{mL}$ aprotinin). Protein concentrations in the lysates were determined using BCA protein assay kit from Pierce (Rockford, USA) according to the manufacturer's instructions. $20 \mu \mathrm{g}$ of protein preheated for $5 \mathrm{~min}$ at $99^{\circ} \mathrm{C}$ in sample buffer (containing TRIS-HCl, SDS, DTT, bromphenol blue, and glycerol) were subjected to a $8 \%$ (MRP2/ABCC2) or 10\% (Pgp/ABCB1) SDS polyacrylamide gel electrophoresis (SDS-PAGE) and electrotransferred to nitrocellulose nitrate membranes (Optitran BA-S 85, Schleicher \& Schuell BioScience, Dassel, Germany). Blots were blocked by incubation for $1 \mathrm{~h}$ with $5 \%$ skim milk (w/v) in phosphate buffered saline containing $0.1 \%$ Tween-20. Immunoblot analysis was carried out with a monoclonal antibody raised against Pgp/ABCB1 (Clone F4, Sigma, Saint Louis, USA), MRP2/ABCC2 (Anti-MRP2, Sigma, Saint Louis, USA), or $\beta$-actin (Clone AC-74) (Sigma-Aldrich, Taufkirchen, Germany) utilised in a dilution of 1:100 (Pgp/ABCB1), 1:250 (MRP2/ABCC2), and 1:40 000 ( $\beta$-actin), respectively, in the TRIS-buffered saline containing $0.1 \%$ Tween- 20 . The blots were then washed extensively and incubated with horseradish peroxidase-linked secondary antibody (GEHealthcare, Munich, Germany). Bands were visualised by enhanced chemiluminescence 
using $10 \mathrm{ml} 100 \mathrm{mM}$ TRIS (pH 8.5), $25 \mu 190$ mM p-coumaric acid, $50 \mu 1250 \mathrm{mM}$ luminol, and $3 \mu 130 \% \mathrm{H}_{2} \mathrm{O}_{2}$.

\subsection{Functional assay for Pgp (rhodamine-123 efflux assay)}

To also exemplify the repression of function in addition to RNA and protein repression Pgp activity was measured in oxaliplatin treated LS180 cells using rhodamine-123 efflux. In brief, cells were harvested after the incubation period and incubated with rhodamine-123 at a concentration of $0.4 \mu \mathrm{M}$ on a rotary shaker $\left(30 \mathrm{~min}, 37^{\circ} \mathrm{C}, 450 \mathrm{rpm}\right)$. Subsequently, cells were washed with precooled medium containing $2 \% \operatorname{FCS}\left(4^{\circ} \mathrm{C}\right)$ and incubated another 50 min at 37 ${ }^{\circ} \mathrm{C}$ in rhodamine-123 free medium containing $2 \%$ FCS to allow rhodamine123 efflux. After washing the cells with precooled PBS containing 2\% FCS they were resuspended in this buffer and rhodamine-123 fluorescence was measured in gated LS180 cells using a 530 bandpass filter in a Becton Dickinson LSRII flow cytometer. In each sample 30.000 cells were counted. Median rhodamine-123 fluorescence was determined in cells treated with oxaliplatin and compared to median rhodamine-123 fluorescence of untreated control cells. We did not use the inhibition ratio as described before $[21,22]$, because Pgp/ABCB1 activity is inherently very low in LS180 cells and after reduction by oxaliplatin the inhibition ratio goes towards 1 . A change in intracellular rhodamine-123 fluorescence is only an indication and not a proof for changes in Pgp activity, because rhodamine-123 is also transported by other drug transporters.

\subsection{Cytotoxicity assay}

Oxalate and DACH were screened for cytotoxic effects prior to Pgp/ABCB1 and BCRP/ABCG2 inhibition assays with the Cytotoxicity Detection Kit, a colorimetric assay for the quantification of lactate dehydrogenase activity released from the cytosol of damaged cells. Cytotoxicity was expressed as a percentage of the effect obtained with the positive control (total cell lysis). Neither oxalate nor DACH exhibited relevant cytotoxic effects. 


\subsection{Impact of oxaliplatin metabolites on Pgp activity (calcein uptake assay)}

For evaluation of possible Pgp inhibiting properties of the oxaliplatin metabolites oxalate (4-4000 $\mu \mathrm{M})$ and DACH $(1-2000 \mu \mathrm{M})$ were tested in a calcein assay. The assay was conducted and validated as described previously $[19,23]$. Each experiment was performed in duplicate on different days.

\subsection{Impact of oxaliplatin metabolites on BCRP/ABCG2 activity (PhA efflux)}

The BCRP/ABCG2 inhibition assay using PhA as fluorescent BCRP/ABCG2 substrate was performed for oxalate $(1 \mu \mathrm{M}$ to $4000 \mu \mathrm{M})$ and $\mathrm{DACH}(1 \mu \mathrm{M}$ to $2000 \mu \mathrm{M})$ as described and validated previously [24]. Each experiment was performed at least in triplicate or in duplicate (if no inhibition was observed) on different days.

\subsection{Impact of oxaliplatin metabolites on MRP1 activity}

For evaluation of possible MRP1 inhibiting properties of the oxaliplatin metabolites oxalate and DACH, both compounds were studied in a MRP1 inhibition assay as described elsewhere [26] with minor modifications. In brief, MDCKII cells over-expressing MRP1 (6x10 cells) or the corresponding parental cell line were seeded on coverslips in a closed miniperfusion chamber directly before the experiment and preincubated for $30 \mathrm{~min}$ with or without the test compound in darkness at $37^{\circ} \mathrm{C}$ in $1 \mathrm{ml}$ cell culture medium. CMFDA in a final concentration of $50 \mathrm{nM}$ was subsequently added and incubated for $10 \mathrm{~min}$. The selective MRP inhibitor MK571 (BIOMOL Research Laboratories, Plymouth Meeting, PA) served as positive control at a concentration of 50 $\mu \mathrm{M}$.

\subsection{Glutathione assay}

Glutathione concentrations were measured using the QuantiChrom Glutathione Assay Kit. The assay was conducted in duplicate according to the manufacturer's instruction with the minor modification of using $2 \times 10^{7}$ cells. 


\subsection{Effects of combinations of oxaliplatin components}

Briefly, either oxalate and $\mathrm{Cl}_{2}$-DACH-Pt or oxalate and cisplatin were concurrently added to MDCKII cells at a fixed ratio of concentrations that were previously applied in the corresponding single drug assays. Proliferation assays were performed as described above. Data were subsequently analysed by the median effect method of Chou and Talalay [25]. Calculated combination indices (CIs) indicate synergism, summation, or antagonism of the two drugs, if CI $<1, \mathrm{CI}=1$, or $\mathrm{CI}>1$, respectively.

We determined $\mathrm{IC}_{50}$-values and slopes of the concentration-response curves according to the standard Hill equation. All deduced $\mathrm{D}_{\mathrm{x}}\left(=\mathrm{IC}_{\mathrm{x}}\right)$ values were calculated using GraphPad QuickCalcs. For each level of inhibition in this study $\left(\mathrm{IC}_{10}, \mathrm{IC}_{30}, \mathrm{IC}_{50}, \mathrm{IC}_{70}, \mathrm{IC}_{90}\right)$, the $\mathrm{CI}$ was calculated under the assumption that the two agents were mutually non-exclusive.

\subsection{Effect of acetylcysteine treatment on glutathione level and resistance}

To further clarify the relation between glutathione levels and resistance to $\mathrm{Cl}_{2}$-DACH-Pt, LS180 cells were incubated with $1 \mathrm{mM}, 5 \mathrm{mM}$, or $10 \mathrm{mM}$ of acetylcysteine for $72 \mathrm{~h}$. After incubation, cellular glutathione levels were measured as described above. For proliferation assays, cells were seeded in 96-well plates containing the respective amount of acetylcysteine and were subsequently treated as described above.

\subsection{Statistical analysis}

Data are presented as means \pm S.D. and were analysed using GraphPad Prism ${ }^{\circledR}$ Version 5.0 and InStat Version 3.05 (GraphPad Software, San Diego, CA, USA). Differences in resistance or mRNA expression following drug incubation compared with the respective vehicle control were tested using two-tailed unpaired student's t-test compared to the corresponding untreated control. A P-value of $\leq 0.05$ was considered significant. 


\section{Results}

3.1Differential effects of FOLFOX components on resistance/sensitivity of LS180 cells:

After incubation with oxaliplatin or 5-FU for $72 \mathrm{~h}$, LS180 cells were significantly more sensitive to oxaliplatin. $\mathrm{IC}_{50}$ values were approximately $50 \%$ of vehicle treated cells. The effect of $5-\mathrm{FU}$ preincubation on 5-FU activity was even greater but did not reach statistical significance. In contrast, leucovorin did not influence the vulnerability of the cells to any of the drugs applied (Fig. 1).

3.2 Differential effects of FOLFOX components on mRNA expression of drug transporters: With the exception of hOCT2/SLC22A2, which was suppressed during leucovorin treatment, leucovorin had no impact on drug transporter mRNA expression. 5-FU treatment significantly suppressed ATP7B and hOCT2/SLC22A2 and increased MRP2/ABCC2 (5.8-fold) mRNA expression. Oxaliplatin treatment only led to a significant suppression of Pgp/ABCB1 (Fig. 2). 3.3 Effects of oxaliplatin on Pgp/ABCB1 protein expression and activity of 5-FU on MRP2/ABCC2 protein expression in LS180 cells:

To verify whether the changes in mRNA expression of Pgp/ABCB1 and MRP2/ABCC2 observed in LS180 cells after treatment with oxaliplatin and 5-FU translate into protein changes we also analysed the protein expression by western blot. MRP2/ABCC2 protein expression was significantly increased in LS180 cells after incubation with 5-FU (Fig. 3) and Pgp/ABCB1 protein expression and activity was significantly reduced in LS180 cells after incubation with oxaliplatin as demonstrated by western blot (data not shown) and rhodamine-123 efflux assay (decrease of Pgp activity by $16 \% ; \mathrm{P}=0.02$ ).

3.4 Impact of selected human ABC-transporters on cytostatic activity of FOLFOX components: 
To estimate the impact of individual ABC-transporters on the cytostatic effect of FOLFOX components, proliferation assays with MDCKII cells over-expressing single human ABCtransporters were conducted. The corresponding parental cell line was used as a control. None of the investigated ABC-transporters mediated resistance to leucovorin. Cells over-expressing $\mathrm{BCRP} / \mathrm{ABCG} 2$ or MRP1/ABCC1 were extraordinarily resistant to 5-FU, whereas BCRP/ABCG2, MRP2/ABCC2, and MRP3/ABCC3 over-expressing cell lines were hypersensitive to oxaliplatin (Fig. 4).

3.5 Impact of selected human ABC-transporters on cytostatic activity of oxaliplatin metabolites, cisplatin, and combinations of compounds:

MDCKII cells over-expressing BCRP/ABCG2 or MRP2/ABCC2 were partially resistant to cisplatin. All investigated ABC-transporters mediated resistance to oxalate. In addition, cells over-expressing Pgp/ABCB1, MRP1/ABCC1, MRP2/ABCC2, or MRP3/ABCC3 were also resistant to DACH. MDCKII cells over-expressing Pgp/ABCB1 were partially resistant and those expressing MRP1/ABCC1 were hypersensitive to $\mathrm{Cl}_{2}$-DACH-Pt. When oxalate and $\mathrm{Cl}_{2}-\mathrm{DACH}$ Pt were combined, MDCKII cells over-expressing Pgp/ABCB1, MRP1/ABCC1, or MRP2/ABCC2 were resistant to this combination. In contrast, MDCKII cells over-expressing BCRP/ABCG2 or MRP3/ABCC3 were hypersensitive. Control experiments with the combination of oxalate with cisplatin revealed MDCKII-MRP1 cells to be partially resistant and MDCKII cells over-expressing MRP3/ABCC3 to be hypersensitive to this combination (Fig. 5). 3.6 Measurement of glutathione content and correlation with cytostatic activity of $\mathrm{Cl}_{2}-\mathrm{DACH}-\mathrm{Pt}$ : Normalised to parental MDCKII cells, MDCKII cells over-expressing Pgp/ABCB1 revealed significantly higher glutathione values, whereas MDCKII cells over-expressing MRP1/ABCC1 or MRP3/ABCC3 contained significantly less glutathione. The difference in glutathione content between MDCKII cells over-expressing MRP2/ABCC2 or BCRP/ABCG2, and their parental 
counterpart was approximately $10 \%$, but did not reach statistical significance (data not shown). However, there was a strong correlation (Spearman correlation coefficient $r=0.94$ ) between glutathione content and $\mathrm{IC}_{50}$ of $\mathrm{Cl}_{2}$-DACH-Pt (Fig. 6).

\subsection{Evaluation of interaction between oxalate and $\mathrm{Cl}_{2}-\mathrm{DACH}-\mathrm{Pt}$ :}

Analysis of combination indices revealed that the combination of oxalate and cisplatin acts additively (Fig. 7), whereas the interaction of oxalate and $\mathrm{Cl}_{2}$-DACH-Pt was synergistic with CI values generally $<1$ (Fig. 8). Different extents of proliferation inhibition resulted in different degrees of synergism. However, in any cell line tested the combination indices for the combination of oxalate and $\mathrm{Cl}_{2}$-DACH-Pt were significantly lower than the corresponding values in the control experiment comprising the combination of oxalate and cisplatin suggesting oxalate to be a pharmacodynamically relevant ligand that specifically contributes to oxaliplatin's action. In addition, the most profound synergistic interaction was always observed in MDCKII overexpressing MRP3/ABCC3 (Fig. 7,8).

\subsection{Impact of oxalate and DACH on Pgp/ABCB1, BCRP/ABCG2, and MRP1/ABCC1 activity}

To exclude that FOLFOX synergism can be attributed to drug accumulation mediated by ABCtransporter inhibition by oxaliplatin metabolites, both oxalate and DACH were screened for Pgp/ABCB1, BCRP/ABCG2, and MRP1/ABCC1 inhibiting properties up to concentrations of 4 $\mathrm{mM}$ and $2 \mathrm{mM}$, respectively. Neither oxalate nor DACH had profound impact on Pgp/ABCB1 or BCRP/ABCG2 activity. Only at $2 \mathrm{mM}$ DACH showed slight BCRP/ABCG2 and MRP1/ABCC2 inhibiting properties (data not shown).

\subsection{Effect of acetylcysteine treatment on glutathione level and resistance}

To increase the cellular glutathione levels, cells were treated with different concentrations of acetylcysteine. Only $10 \mathrm{mM}$ acetylcysteine caused a significant increase in glutathione content $(1.8$-fold $\pm 0.6, \mathrm{p}<0.05)$. Cells being cultured in media containing 5 or $10 \mathrm{mM}$ acetylcysteine 
were significantly more resistant to $\mathrm{Cl}_{2}-\mathrm{DACH}-\mathrm{Pt}$ than their respective untreated counterparts (resistance factor for $5 \mathrm{mM}$ : $18.2 \pm 0.4, \mathrm{p}<0.0001$; for $10 \mathrm{mM}: 22.1 \pm 3.9, \mathrm{p}<0.0001$ ). 


\section{Discussion}

Multidrug resistance increasingly requires anti-cancer combination therapy. The aim of this in vitro study was to elucidate the transcriptional alterations of drug transporters' mRNA expressions and functional alterations following the exposure of LS180 cells to individual components of the FOLFOX regimen. Functionally, preincubation with oxaliplatin or 5-FU both sensitised LS180 cells to oxaliplatin. Incubation with oxaliplatin was accompanied by a decrease of mRNA and protein expression of Pgp/ABCB1. In addition, oxaliplatin led to a significant increase of accumulation of rhodamine-123 in LS180 cells indicating diminished Pgp function. Although we could not demonstrate leucovorin to be a substrate of Pgp in MDCKII cells (Fig. 4), it is plausible that suppression of this drug transporter can lead to leucovorin accumulation with subsequently enhanced efficacy of 5-FU (Fig.1) as Pgp was formerly reported to efflux folate derivatives such as methotrexate [27].

5-FU treatment led to several statistically significant mRNA alterations. First, mRNA expression of one of oxaliplatin's importers (hOCT2/SLC22A2) [11] and of the exporter ATP7B [28] was suppressed. Secondly, 5-FU increased mRNA and protein expression of MRP2/ABCC2. These data raised the question of whether expressional alterations of drug transporters - especially MRP over-expression - could generally increase drug efficacy. To further clarify the relationship between $\mathrm{ABC}$-transporter expression and cytostatic properties of FOLFOX components proliferation assays with MDCKII cells over-expressing individual human ABC-transporters and the corresponding parental cell line were performed. In contrast to other reports [6], none of the investigated $\mathrm{ABC}$-transporters mediated resistance to leucovorin, which might be attributable to a different in vitro cell model used by us. Over-expression of BCRP/ABCG2 and MRP1/ABCC1 was related to resistance to 5-FU, as it was previously demonstrated for BCRP [29]. To date, there are no reports demonstrating MRP1 to be a MDR-mediating transporter of 5-FU. In 
addition, $\mathrm{BCRP} / \mathrm{ABCG} 2$ and MRP1/ABCC1 mediated resistance to 5-FU could also be the result of their ability to extrude folates [6] and thereby bypassing the biochemical synergism between folates and 5-FU. Over-expression of BCRP/ABCG2, MRP2/ABCC2, and MRP3/ABCC3 was associated with hypersensitivity to oxaliplatin suggesting that 5-FU mediated induction of MRPs/ABCCs in LS180 cells provoked hypersensitivity to oxaliplatin. These results are in contrast to those of Ceckova et al. [30], who demonstrated MDCKII cells transfected with BCRP transporter and enhanced GFP (EGFP) to be resistant to oxaliplatin in comparison to the nontransfected parental cells suggesting BCRP to be an oxaliplatin resistance mediating $\mathrm{ABC}$ transporter. To date, there is no obvious rationale for this discrepancy. However, the authors also attribute their findings with Pt-drugs at least partly to the high expression of EGFP in their cell system.

Oxaliplatin is non-enzymatically metabolised into several distinct moieties such as oxalate and the cytostatically active remnant $\mathrm{Cl}_{2}$-DACH-Pt [31] Proliferation assays with these compounds indicate that oxalate is a substrate of all $\mathrm{ABC}$-transporters investigated. $\mathrm{DACH}$ seems to be a substrate for at least Pgp/ABCB1, MRP1/ABCC1, MRP2/ABCC2, and MRP3/ABCC3. The only moderate increases of $\mathrm{IC}_{50}$ values $(<50 \%)$ suggest that $\mathrm{Cl}_{2}$-DACH-Pt is not a substrate of Pgp/ABCB1, BCRP/ABCG2, MRP2/ABCC2, or MRP3/ABCC3. In contrast, over-expression of MRP1/ABCC1 was associated with hypersensitivity to this oxaliplatin metabolite suggesting better effiacay of oxaliplatin in tumours over-expressing this particular ABC-transporter. Because oxaliplatin is a much more effective cytostatic agent than its metabolite $\mathrm{Cl}_{2}-\mathrm{DACH}-\mathrm{Pt}$, we applied the mathematical procedure introduced by Chou and Talalay to investigate oxalate's contribution to the cytostatic properties of oxaliplatin [25]. By combining oxalate and $\mathrm{Cl}_{2^{-}}$ DACH-Pt oxaliplatin was supposed to be reconstituted in vitro. We combined the same concentrations as in the corresponding single substance experiments to draw unbiased 
conclusions from this combination experiment. Comparison with control experiments comprising the combination of oxalate and cisplatin revealed that oxalate synergistically amplified $\mathrm{Cl}_{2-}$ DACH-Pt action highlighting its relevance for oxaliplatin. As shown in Fig. 6, sensitivity to $\mathrm{Cl}_{2}$ DACH-Pt correlates with glutathione content in MDCKII cells and increasing glutathione concentration significantly increased resistance against $\mathrm{Cl}_{2}-\mathrm{DACH}-\mathrm{Pt}$. These findings therefore suggest that the oxalato ligand of oxaliplatin contributes to oxaliplatin's cytostatic effect by a further decrease of cellular glutathione content [15] thus attenuating the detoxification capacity of the cells.

We therefore propose the following mechanism that might contribute to FOLFOX synergism: 5FU mediated suppression of ATP7B leads to diminished sequestration capacities for oxaliplatin. Concurrently, over-expression of MRPs increases efflux of reduced glutathione and thereby reduces the cellular capacities of detoxifying oxaliplatin or its active metabolite (Fig. 9). In addition, oxalate also decreases glutathione levels hence further amplifying oxaliplatin action. In contrast, the impact of the observed down-regulation of the oxaliplatin importer hOCT2/SLC22A2 remains open as it did not cause oxaliplatin resistance in our experimental setting.

Moreover, our results offer an explanation for the observation by Langer et al. showing high pretherapeutic MRP1 expression in locally advanced adenocarcinomas of the oesophagus to be beneficial for the treatment with Pt drugs like cisplatin [32].

In conclusion, this in vitro study yields further insight into the potential mechanism of synergistic action of FOLFOX combination chemotherapy. First, anti-cancer drugs can lead to several alterations of drug transporters expression potentially favouring reciprocal accumulation of drugs leading to superior efficacy. Secondly, both down- and up-regulation of ABC-transporter expression can lead to higher drug efficacy confirming earlier findings [33-35]. 


\section{Acknowledgements}

Dirk Theile was funded by grant \#107173 from the "German Cancer Aid". 


\section{References}

[1] Andre T, Boni C, Mounedji-Boudiaf, Navarro M, Tabernero J, Hickish T et al. Oxaliplatin, fluorouracil, and leucovorin as adjuvant treatment for colon cancer. N Engl J Med 2004;350:2343-51.

[2] Candeil L, Gourdier I, Peyron D, Vezzio N, Copois V, Bibeau F et al. ABCG2 overexpression in colon cancer cells resistant to SN38 and in irinotecan-treated metastases. Int J Cancer 2004;109:848-54.

[3] Calcagno AM, Ludwig JA, Fostel JM, Gottesman MM, Ambudkar SV. Comparison of drug transporter levels in normal colon, colon cancer, and Caco-2 cells: impact on drug disposition and discovery. Mol Pharm 2006;3:87-93.

[4] Gottesman MM, Fojo T, Bates SE. Multidrug resistance in cancer: role of ATP-dependent transporters. Nat Rev Cancer 2002;2:48-58.

[5] Huang L, Wang C, Zheng W, Liu R, Yang J, Tang C. Effects of celecoxib on the reversal of multidrug resistance in human gastric carcinoma by downregulation of the expression and activity of P-glycoprotein. Anticancer Drugs 2007;18:1075-80.

[6] Hooijberg JH, de Vries NA, Kaspers GJ, Pieters R, Jansen G, Peters GJ. Multidrug resistance proteins and folate supplementation: therapeutic implications for antifolates and other classes of drugs in cancer treatment. Cancer Chemother Pharmacol 2006;58:1-12. 
[7] Pratt S, Shepard RL, Kandasamy RA, Johnston PA, Perry W, Dantzig AH. The multidrug resistance protein 5 (ABCC5) confers resistance to 5-fluorouracil and transports its monophosphorylated metabolites. Mol Cancer Ther 2005;4:855-63.

[8] Oguri T, Bessho Y, Achiwa H, Ozasa H, Maeno K, Maeda H et al. MRP8/ABCC11 directly confers resistance to 5-fluorouracil. Mol Canc Ther 2007;6:122-7.

[9] Song IS, Savaraj N, Siddik ZH, Liu P, Wie Y, Wu CJ et al. Role of human copper transporter Ctr1 in the transport of platinum-based antitumor agents in cisplatin-sensitive and cisplatinresistant cells. Mol Cancer Ther 2004;3:1543-9.

[10] Samimi G, Safaei R, Katano K, Holzer AK, Rochdi M, Tomioka M et al. Increased expression of the copper efflux transporter ATP7A mediates resistance to cisplatin, carboplatin and oxaliplatin in ovarian cancer cells. Clin Cancer Res 2004;10:4661-9.

[11] Zhang S, Lovejoy KS, Shima JE, Lagpacan LL, Shu Y, Lapuk A et al. Organic cation transporters are determinants of oxaliplatin cytotoxicity. Cancer Res 2006;66:8847-57.

[12] Perez R, Hamilton TC, Ozols RF. Resistance to alkylating agents and cisplatin: insights from ovarian carcinoma modell systems. Pharmacol Ther 1990;48:19-27.

[13] El-akawi Z, Abu-hadid M, Perez R, Glavy J, Zdanowicz J, Creaven PJ et al. Altered glutathione metabolism in oxaliplatin resistant ovarian carcinoma cells. Cancer Lett 1996;105:514. 
[14] Ballatori N, Hammond CL, Cunningham JB, Krance SM, Marchan R. Molecular mechanism of reduced glutathione transport: role of the MRP/CFTR/ABCC and OATP/SLC21A families of membrane proteins. Toxicol Appl Pharmacol 2005;204:238-55.

[15] Rashed T, Menon M, Thamilselvan S. Molecular mechanism of oxalate-induced free radical production and glutathione redox imbalance in renal epithelial cells: effect of antioxidants. Am J Nephrol 2004;24:557-68.

[16] Scheid C, Koul H, Hill WA, Luber-Narod J, Kennington L, Honeyman T et al. Oxalate toxicitiy in LLC-PK1 cells: role of free radicals. Kidney Int 1996;49:413-9.

[17] Bulluss GH, Knott KM, Ma ES, Aris SM, Alvarado E, Farrell N. Trans-platinum planar amine compounds with $\left[\mathrm{N}_{2} \mathrm{O}_{2}\right]$ ligand donor sets: effects of carboxylate leaving groups and steric hindrance on chemical and biological properties. Inorg Chem 2006;45:5733-5.

[18] Weiss J, Herzog M, König S, Storch CH, Ketabi-Kiyanvash N, Haefeli WE. Induction of multiple drug transporters by efavirenz. J Pharmacol Sci 2009;109:242-50.

[19] Storch CH, Theile D, Lindenmaier H, Haefeli WE, Weiss J. Comparison of the inhibitory activity of anti-HIV drugs on P-glycoprotein. Biochem Pharmacol 2007;73:1573-81. 
[20] Peters T, Lindenmaier H, Haefeli WE, Weiss J. Interaction of the mitotic kinesin Eg5 inhibitor monastrol with P-glycoprotein. Naunyn Schmiedebergs Arch Pharmacol 2006;372:2919.

[21] Albermann N, Schmitz-Winnenthal FH, Z'graggen K, Volk C, Hoffmann MM, Haefeli WE et al. Expression of the drug transporters MDR1/ABCB1, MRP1/ABCC1, MRP2/ABCC2, BCRP/ABCG2, and PXR in peripheral blood mononuclear cells and their relationship with the expression in intestine and liver. Biochem. Pharmacol 2005;70:949-58.

[22] Weiss J, Weis N, Ketabi-Kiyanvash N, Storch CH, Haefeli WE. Comparison of the induction of P-glycoprotein activity by nucleotide, nucleoside, and non-nucleoside reverse transcriptase inhibitors. Eur J Pharmacol 2008;579:104-9.

[23] Weiss J, Dormann S-MG, Martin-Facklam M, Kerpen CJ, Ketabi-Kiyanvash N, Haefeli WE. Inhibition of P-glycoprotein by newer antidepressants J Pharmacol Exp Ther 2003;305:197-204.

[24] Weiss J, Rose J, Storch CH, Ketabi-Kiyanvash N, Sauer A, Haefeli WE et al. Modulation of human BCRP (ABCG2) activity by anti-HIV drugs. J Antimicrob Chemother 2007;59:238-45.

[25] Chou TC, Talalay P. Quantitative analysis of dose-effect relationships: the combined effects of multiple drugs or enzyme inhibitors. Adv Enzyme Regul 1984;22:27-55. 
[26] Weiss J, Theile D, Ketabi-Kiyanvash N, Lindenmaier H, Haefeli WE. Inhibition of MRP1/ABCC1, MRP2/ABCC2, and MRP3/ABCC3 by nucleoside, nucleotide, and nonnucleoside reverse transcriptase inhibitors. Drug Metab Dispos 2007;35:340-4.

[27] De Graaf D, Sharma RC, Mechetner EB, Schimke RT, Roninson IB. P-glycoprotein confers methotrexate resistance in 3 T6 cells with deficient carrier-mediated methotrexate uptake. Proc Natl Acad Sci 1996;93:1238-42.

[28] Safaei R, Howell SB. Copper transporters regulate the cellular pharmacology and sensitivity to Pt drugs. Crit Rev Onc Hematol 2005;53:13-23.

[29] Yuan JH, Cheng JQ, Jiang LY, Ji WD, Guo LF, Liu JJ et al. Breast cancer resistance protein expression and 5-fluorouracil resistance. Biomed Environ Sci 2008;21:290-5.

[30] Ceckova M, Vackova Z, Radilova H, Libra A, Buncek M, Staud F. Effect of ABCG2 on cytotoxicity of platinum drugs: interference of EGFP. Toxicol In Vitro 2008;22:1846-52.

[31] Jerremalm E, Videhult P, Alvelius G, Griffiths WJ, Bergman T, Eksborg S et al. Alkaline hydrolysis of oxaliplatin — isolation and identification of the oxalato monodentate intermediate. J Pharm Sci 2002;91:2116-21.

[32] Langer R, Specht K, Becker K, Ewald P, Bekesch M, Sarbia M et al. Association of pretherapeutic expression of chemotherapy-related genes with response to neoadjuvant chemotherapy in Barrett carcinoma. Clin Cancer Res 2005;11: 7462-9. 
[33] Ludwig JA, Szakacs G, Martin SE, Chu BF, Cardarelli C, Sauna ZE et al. Selective toxicity of NSC73306 in MDR1-positive cells as a new strategy to circumvent multidrug resistance in cancer. Cancer Res 2006;66:4808-15.

[34] Bergman AM, Pinedo HM, Talianidis I, Veerman G, Loves WJ, van der Wilt CL et al. Increased sensitivity to gemcitabine of P-glycoprotein and multidrug resistance-associated protein overexpressing human cancer cell lines. Br J Cancer 2003;88:1963-70.

[35] Warr JR, Bamford A, Quinn DM. The preferential induction of apoptosis in multidrugresistant KB cells by 5-fluorouracil. Cancer Lett 2002;175:39-44. 
Table 1: Primer sequences

Gene $\quad$ Forward primer 5' -3 ' $\quad$ Reverse primer 5' -3 '

\begin{tabular}{|c|c|c|}
\hline$A B C B 1$ & CCCATCATTGCAATAGCAGG & TGTTCAAACTTCTGCTCCTGA \\
\hline$A B C C 1$ & ATGTCACGTGGAATACCAGC & GAAGACTGAACTCCCTTCCT \\
\hline$A B C C 2$ & ACAGAGGCTGGTGGCAACC & ACCATTACCTTGTCACTGTCCATGA \\
\hline$A B C C 3$ & AACTATGCCCCCGATGAGGACCAA & AGAGTGGAGATGGCGTTGAAGGAAG \\
\hline$A B C C 4$ & AAGTGAACAACCTCCAGTTCCAG & GGCTCTCCAGAGCACCATCT \\
\hline$A B C C 5$ & AGGGGCAAGAAAGAGAAGGTGAGG & GAGGGGGTCGTCCAGGATGTAGAT \\
\hline$A B C G 2$ & AGATGGGTTTCCAAGCGTTCAT & CCAGTCCCAGTACGACTGTGACA \\
\hline SLC31A1 & AGCTGGAGAAATGGCTGGAG & AGGTGAGGAAAGCTCAGCATC \\
\hline$A T P 7 A$ & ATGATGAGCTGTGTGGCTTG & TGCCAACCTGAGAAGCAATAG \\
\hline$A T P 7 B$ & TACCCATTGCAGCAGGTGTC & ACTTGAGCTGCAGGGATGAG \\
\hline$S L C 22 A 2$ & TCTACTCTGCCCTGGTTGAATTC & ATGCAGCCCAAGGGTAACG \\
\hline$\beta 2 m g$ & CCAGCAGAGAATGGAAAGTC & CATGTCTCGATCCCACTTAAC \\
\hline G6PDH & ATCGACCACTACCTGGGCAA & TCTGCATCACGTCCCGGA \\
\hline$G U$ & TTCACCAGGATCCACCTCTG & AGCACTCTCGTCGGTGACTG \\
\hline HPRT & CTGGCGTCGTGATTAGTG & CACACAGAGGGCTACAATG \\
\hline RPL13 & GCTCATGAGGCTACGGAAAC & TATTGGGCTCAGACCAGGAG \\
\hline$H U P O$ & AGCTCTGGAGAAACTGCTG & AGCAGCTGGCACCTTATTG \\
\hline
\end{tabular}




\section{Figure legends}

Fig. 1: Impact of incubation of LS180 cells with leucovorin, 5-FU, or oxaliplatin for $72 \mathrm{~h}$ on resistance to leucovorin (black bars), 5-FU (white bars), and oxaliplatin (grey bars), respectively. Resistance factors (RF) were calculated by division of $\mathrm{IC}_{50}$ of preincubated cells with $\mathrm{IC}_{50}$ of native cells. RF values are means \pm S.D. of at least three independent experiments. Statistical significance was tested by Student's unpaired, two-tailed t-test. $* \mathrm{P}<0.05$, ** $\mathrm{P}<0.01$.

Fig. 2: mRNA expression of drug transporters in LS180 cells after incubation with leucovorin (black bars), 5-FU (white bars), or oxaliplatin (grey bars) for $72 \mathrm{~h}$, respectively. Expression levels were related to glucuronidase- $\beta$ mRNA expression and normalised to vehicle treated control. Statistical significance was evaluated using Student's unpaired, two-tailed t-test (compared to the respective vehicle control). Data are expressed as mean \pm S.D. for $\mathrm{n}=5-9{ }^{*} \mathrm{P}<0.05, * * \mathrm{P}<$ 0.01 .

Fig. 3: Western blot analysis of whole cell lysates of LS180 cells treated for $72 \mathrm{~h}$ with $7.14 \mu \mathrm{M}$ 5-FU. Three independent experiments (\#1-3) were conducted. MDCKII (low expression of canine MRP2) and MDCKII-MRP2 (over-expression of human MRP2) cells served as controls. $\beta$-actin served as a marker for approximately similar protein content of all samples.

Fig. 4: Effect of leucovorin, 5-FU, and oxaliplatin on proliferation of MDCKII cells overexpressing Pgp/ABCB1, BCRP/ABCG2, MRP1/ABCC1, MRP2/ABCC2, and MRP3/ABCC3, respectively. Resistance factors $(\mathrm{RF})$ were calculated by division of $\mathrm{IC}_{50}$ of $\mathrm{ABC}$-transporter over-expressing cells with $\mathrm{IC}_{50}$ of parental cells. RF values are means \pm S.D. of at least three 
independent experiments. Statistical significance was evaluated using Student's unpaired, twotailed t-test (compared to the respective vehicle control). $* \mathrm{P}<0.05, * * \mathrm{P}<0.01$.

Fig. 5: Effect of cisplatin, oxalate, $\mathrm{DACH}, \mathrm{Cl}_{2}$-DACH-Pt, combined application of oxalate with $\mathrm{Cl}_{2}$-DACH-Pt, and combined application of oxalate with cisplatin on proliferation of MDCKII cells over-expressing Pgp/ABCB1, BCRP/ABCG2, MRP1/ABCC1, MRP2/ABCC2, and MRP3/ABCC3, respectively. Resistance factors (RF) were calculated by division of $\mathrm{IC}_{50}$ of human $\mathrm{ABC}$-transporter over-expressing cells with $\mathrm{IC}_{50}$ of parental cells. $\mathrm{RF}$ values are means \pm S.D. of at least three independent experiments. Statistical significance was evaluated using Student's unpaired, two-tailed t-test (compared to the respective vehicle control). ${ }^{*} \mathrm{P}<0.05,{ }^{*} * \mathrm{P}$ $<0.01, * * * \mathrm{P}<0.0001$

Fig. 6: Correlation of intracellular glutathione content and $\mathrm{IC}_{50}$ of $\mathrm{Cl}_{2}-\mathrm{DACH}-\mathrm{Pt}$ among $\mathrm{MDCKII}$ cells over-expressing Pgp/ABCB1, BCRP/ABCG2, MRP1/ABCC1, MRP2/ABCC2, MRP3/ABCC3, respectively, and the corresponding parental cell line. Spearman correlation coefficient $(\mathrm{r}=0.94)$ was calculated with six XY pairs; P-value $=0.0167$.

Fig. 7: Median effect analysis of combined cytostatic properties of oxalate and cisplatin in MDCKII cells over-expressing Pgp/ABCB1, BCRP/ABCG2, MRP1/ABCC1, MRP2/ABCC2, MRP3/ABCC3, respectively, and the corresponding parental cell line.

Fig. 8: Median effect analysis of combined cytostatic properties of oxalate and $\mathrm{Cl}_{2}-\mathrm{DACH}-\mathrm{Pt}$ in MDCKII cells over-expressing Pgp/ABCB1, BCRP/ABCG2, MRP1/ABCC1, MRP2/ABCC2, MRP3/ABCC3, respectively, and the corresponding parental cell line. 
Fig. 9: Proposed main mechanism for the synergism of 5-FU and oxaliplatin in the context of FOLFOX chemotherapy: 5-FU mediated suppression of ATP7B leads to diminished sequestration capacities for oxaliplatin into the endoplasmatic reticulum. In addition, induced over-expression of MRPs promotes efflux of reduced glutathione resulting in cellular glutathione depletion, which in turns reduces detoxification capacities for oxaliplatin and its active metabolite. In addition, oxalate can further decrease glutathione levels. 


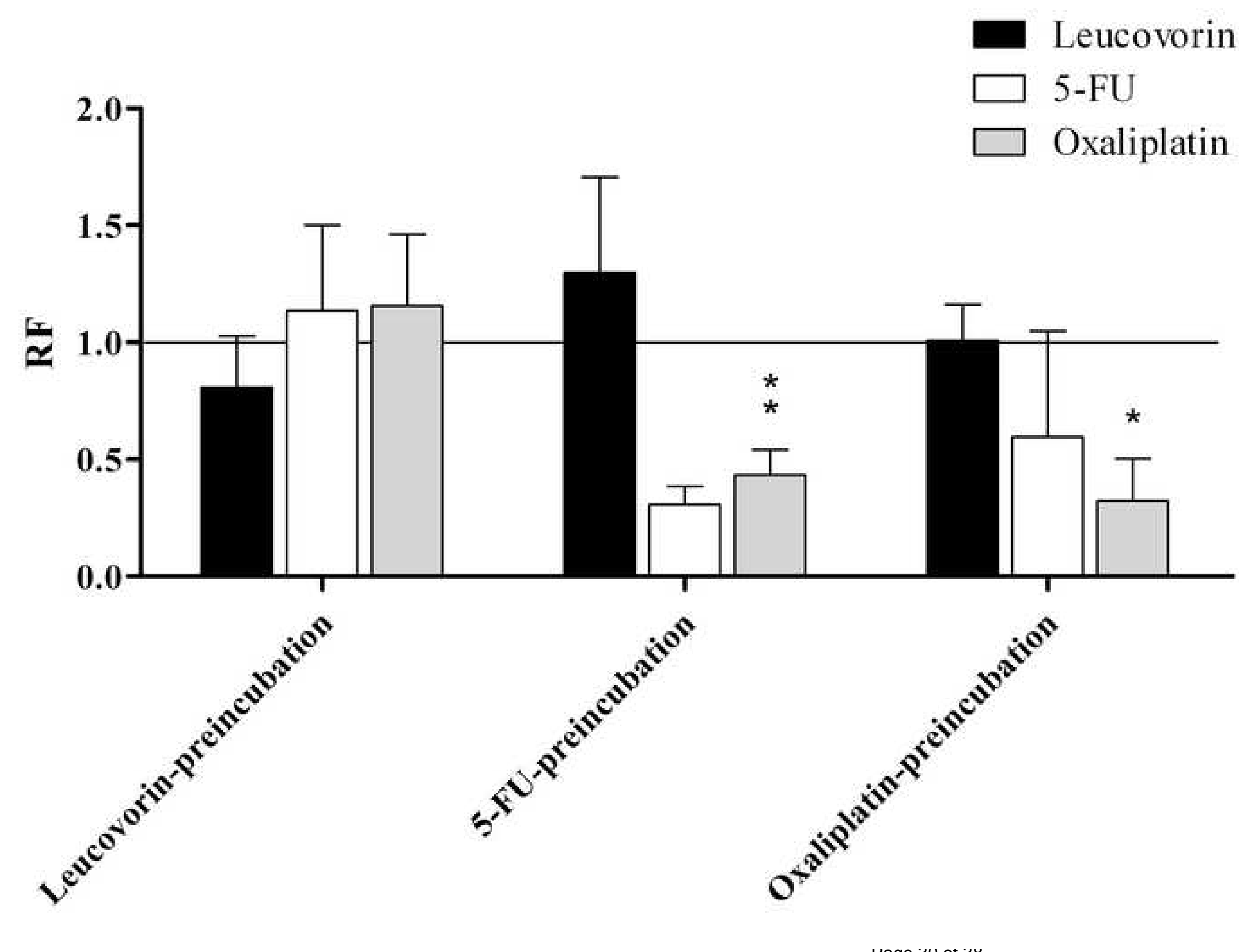

rage 30 or 38
rage su

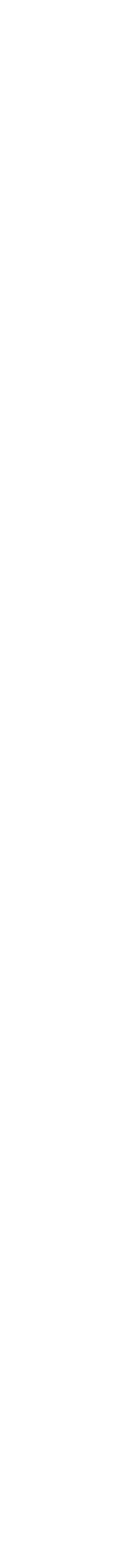

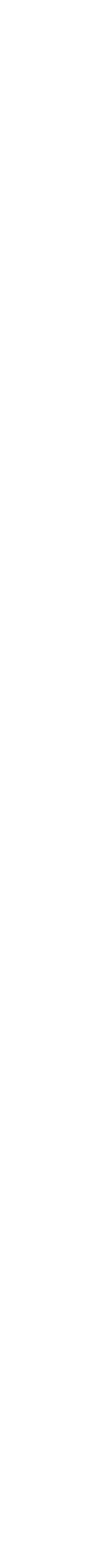

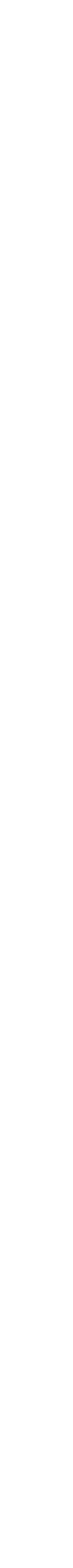




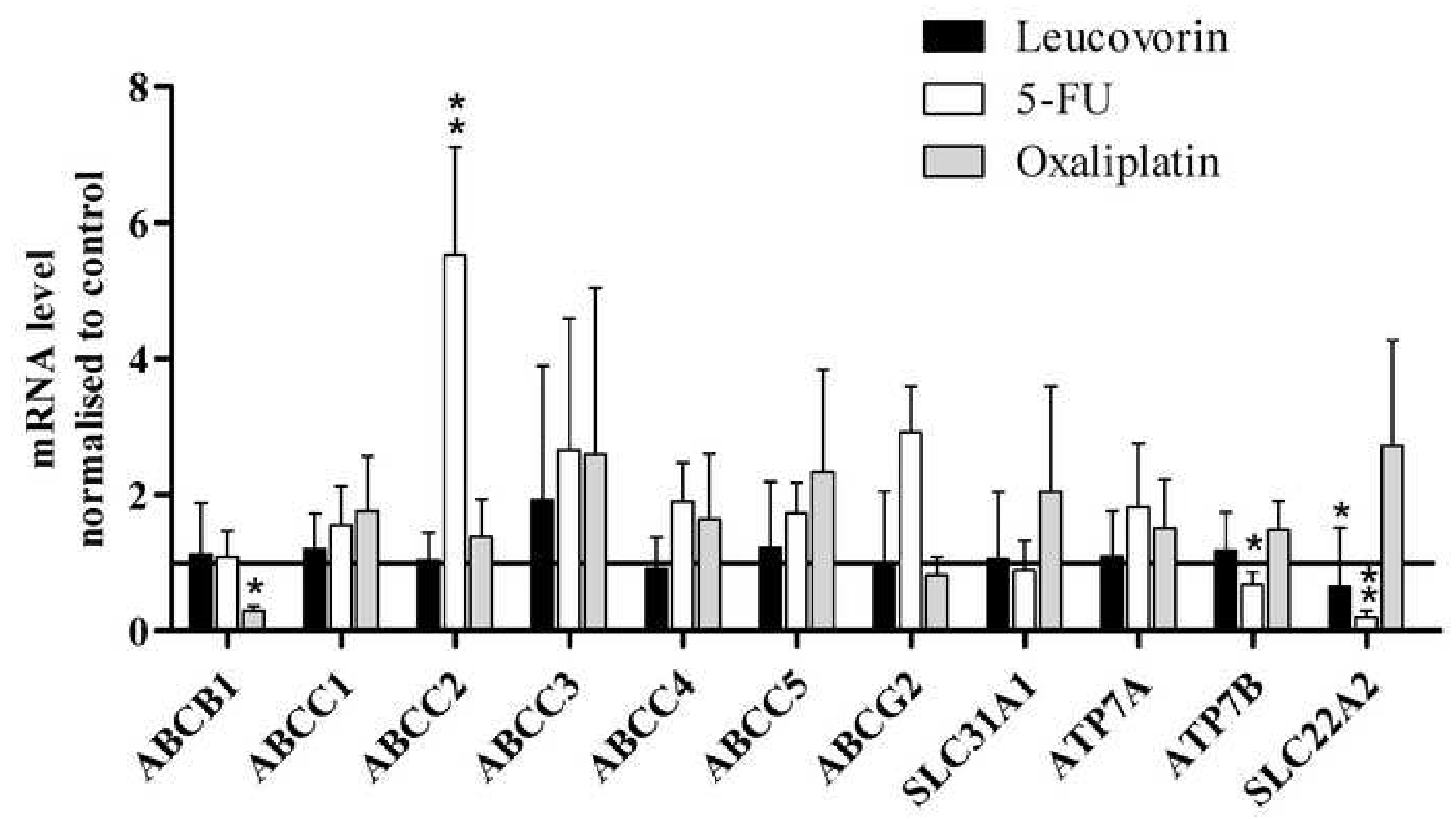




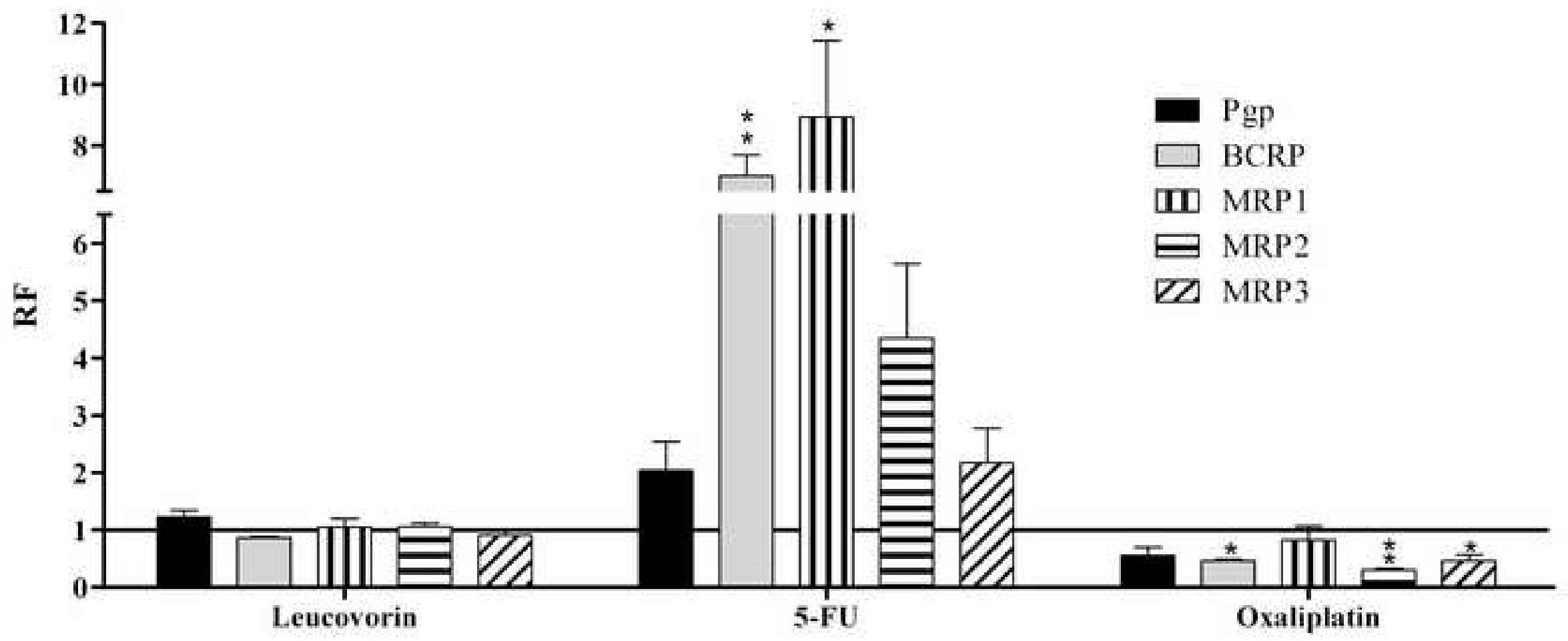




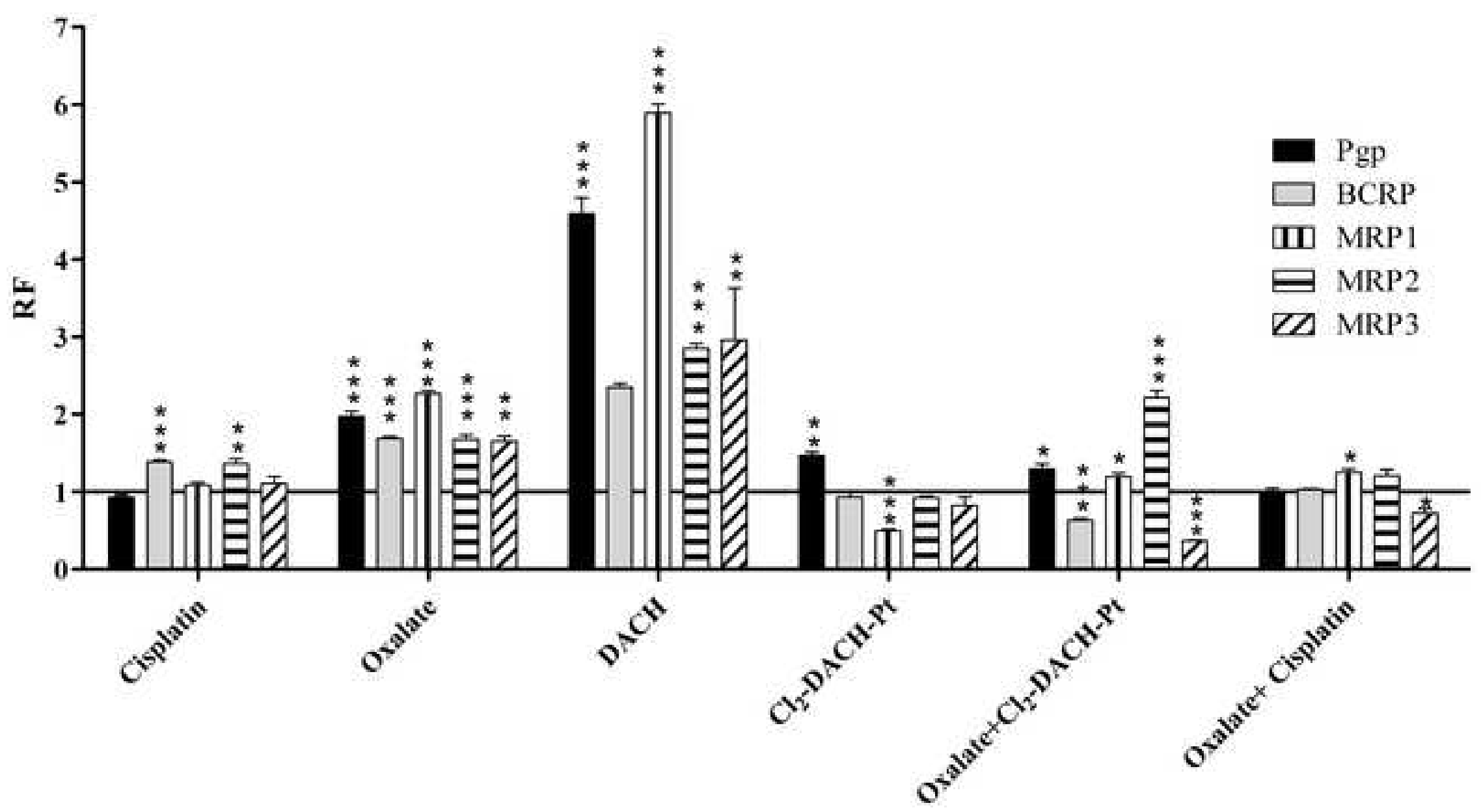




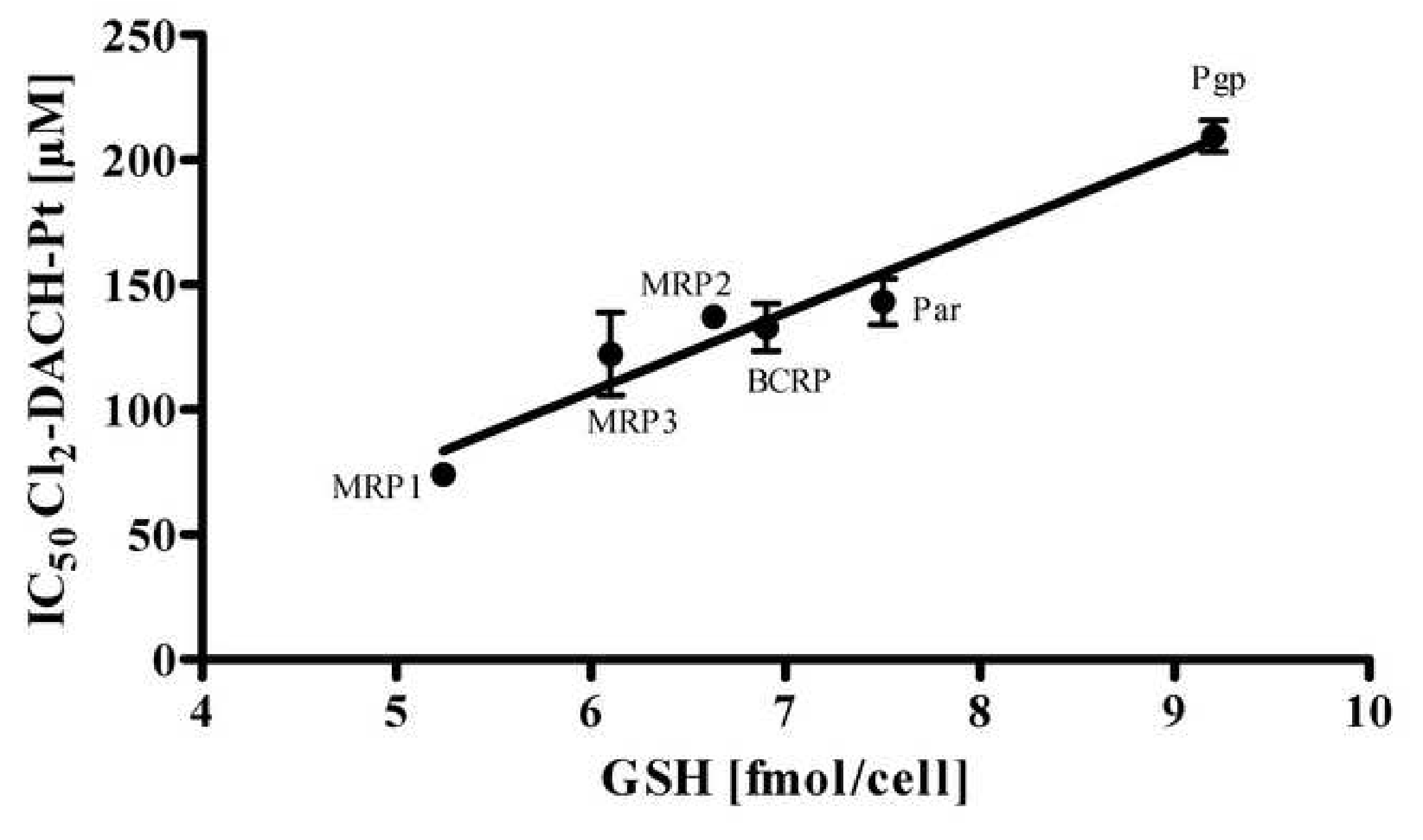

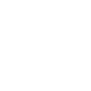




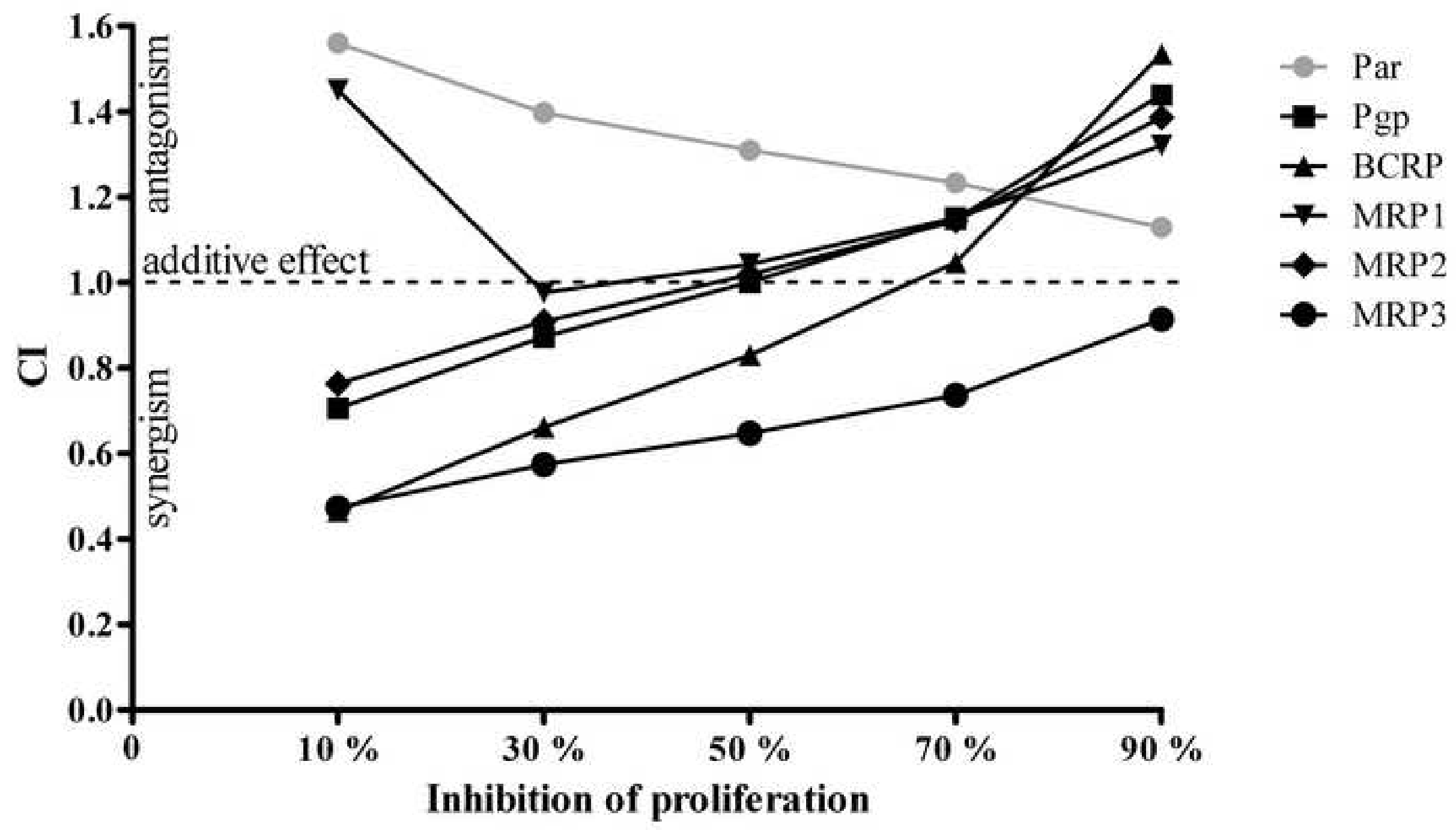




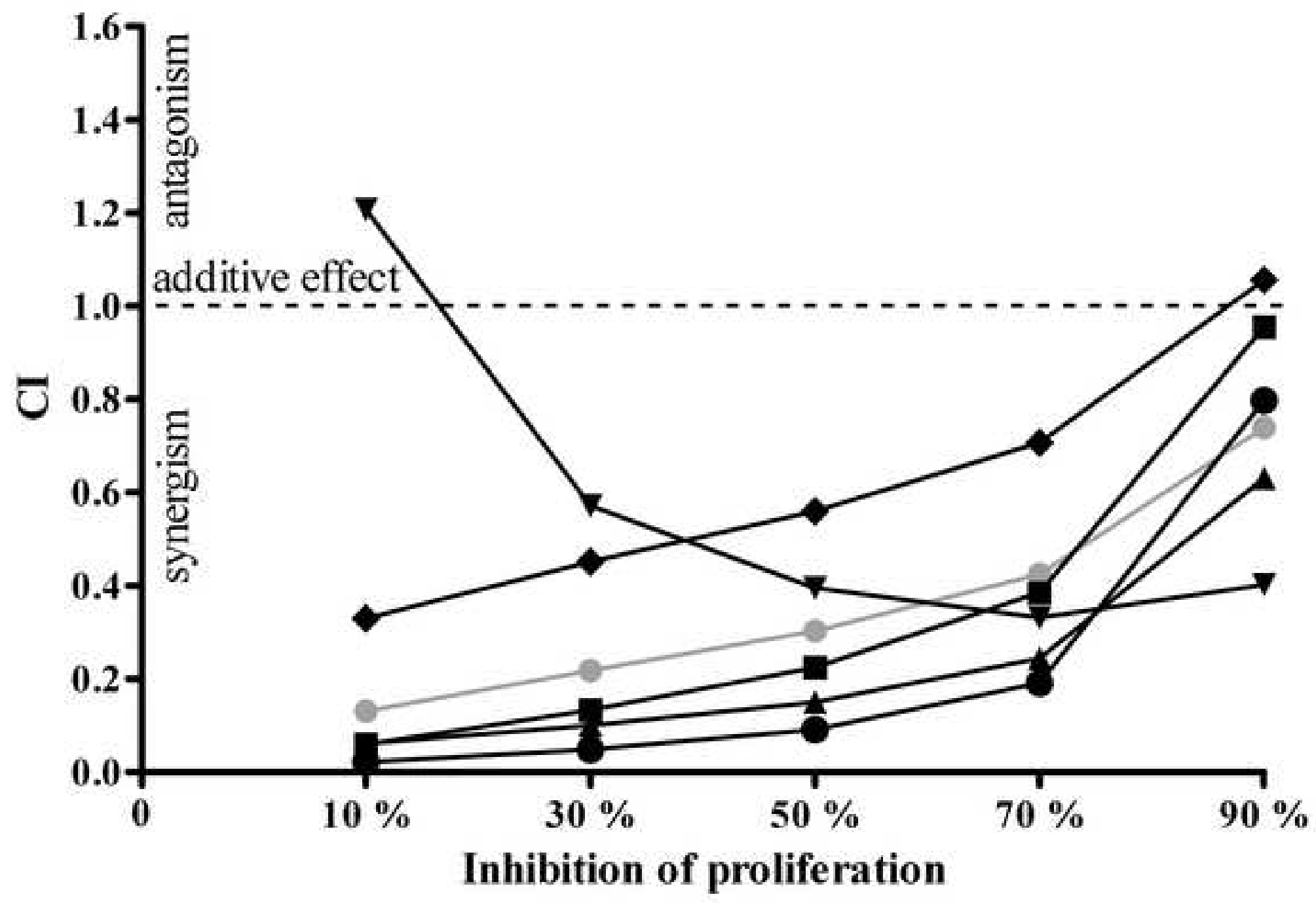

- Par

- Pgp

$\star$ BCRP

- MRP1

- MRP2

- MRP3 


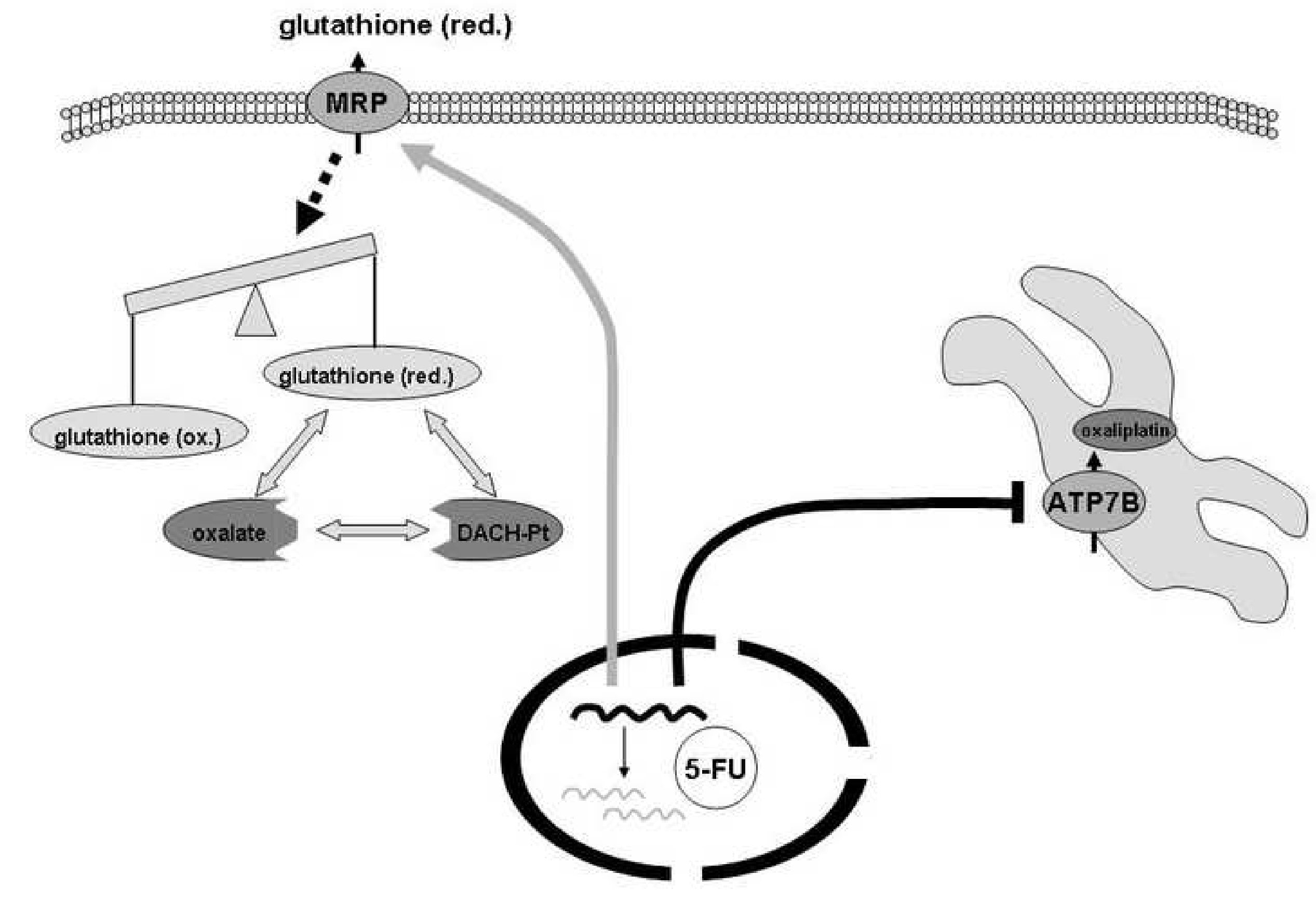

